\title{
Using CEO Succession to Integrate Acquired Organizations: A Contingency Analysis
}

\author{
Shoou-Yih Daniel Lee and Jeffrey A. Alexander* \\ Department of Sociology, University of Illinois at Chicago, 1007 W. Harrison Street, Chicago, IL 60607-7140 and \\ *Department of Health Management and Policy, School of Public Health, The University of Michigan,
} 109 Observatory, Ann Arbor, MI 48109-2029, USA

\begin{abstract}
The study proposes that organizations engaged in related acquisition may encourage CEO succession as a mechanism for integrating acquired organizations. Further, we suggest that the risk of CEO succession at the time of acquisition will vary based on the need for integrative action and the power of acquired organizations. Results show that CEO succession is more likely when the participating organizations have incompatible types of ownership and when acquired CEOs have longer tenure than their counterparts. Conversely, the probability of CEO succession is lower among larger acquired organizations. Performance of the acquired organization does not affect the relationship between related acquisition and CEO succession.
\end{abstract}

\section{Introduction}

Related acquisition involves the purchase and consolidation of firms in the same or related product markets (Ansoff and Weston, 1962; Chatterjee, 1992; Datta, 1991; Datta and Grant, 1990; Harrison et al., 1991). Research has shown that about half of related acquisition activities fail to achieve expected economic and synergistic benefits (Fairburn and Geroski, 1989). Such failures have been attributed to the inability to effectively integrate newly acquired organizations (Cartwright and Cooper, 1993). Although there is a growing interest in post-acquisition integration, our understanding of how integration is actually pursued remains limited.

This study provides an empirical test of the relationship between related acquisition and one such integration strategy - CEO succession in acquired firms. We maintain that the probability of CEO succession is high when all or a majority share of an organization's assets are acquired (through purchase, exchange or gift) by a suitor company. In such a situation, the acquirer may encourage CEO succession as an integrative mechanism to introduce its values, strategic priorities and operational procedures into the new subsidiary. However, it is unlikely that CEO succession will occur in all acquired firms; there may be conditions under which retaining the acquired CEO may facilitate the goals of related acquisition (e.g. the CEO's knowledge of the acquired firm may be needed during the integration phase of acquisition). In this study, we focus on two organizational conditions that may moderate the relationship between related acquisition and CEO succession: the need for integrative action and power of the acquired organization. These arguments are explicated in a theoretical model and tested with longitudinal panel data on all US community hospitals from 1980 to 1988.

The study enhances understanding of postacquisition CEO succession in three respects. First, 
conceptualizing CEO succession as an integrative strategy complements the prevailing contention that takeovers serve as a disciplinary mechanism for weeding out ineffective management (Jensen, 1986; Varian, 1988; Walsh and Seward, 1990). Second, most previous research has been concerned with the main effect of acquisition on CEO succession. Our study identifies factors that condition the likelihood of succession among CEOs of acquired organizations. Such analyses not only improve our understanding of the dynamics of acquisition but also demonstrate the critical role that CEOs play in acquisition processes. Third, our study tests how acquisition-related CEO succession occurs in a population dominated by non-profit organizations. These analyses may therefore extend the generalizability of previous acquisition research on public, for-profit companies to the not-forprofit sector.

\section{Related Acquisition and Integration}

Research on acquisition has commonly taken a financial market approach (Hill and Hoskisson, 1987). This approach views related acquisition as driven primarily by potential economic synergy. It is assumed that synergy can be accomplished by merging previously independent firms (Chatterjee, 1992; Datta, 1991; Datta and Grant, 1990; Harrison et al., 1991).

The financial market perspective points to the underlying motivation and potential economic consequences of consolidation among companies. However, it tends to overlook the importance of integration after the transaction occurs. Unlike conglomerate acquisition that aims to enhance the financial position of the parent corporation by incorporating firms in different businesses, related acquisition focuses on enhancing the overall viability of the corporation through combining the operations and structures of similar, but previously independent, organizations (Datta and Grant, 1990; Singh and Montgomery, 1987). For example, a hospital may acquire other hospitals in the same or adjacent service areas to achieve economies of scale, to avoid costly duplication by offering complementary services, or to form an integrated health-delivery system with hospitals providing different levels of care. Even if services are not allocated rationally among the facilities, management may be integrated to solve problems posed by common regulatory and market environments (Finkler and Horowitz, 1985). To achieve such synergistic benefits, it is often necessary to transform and integrate acquired companies in a manner consistent with the corporation's strategic policies (Buono, Bowditch and Lewis, 1985; Datta, 1991; Pablo, 1994). Such transformation involves learning of new organizational behaviours and adjustment to a new corporate environment, and may also require unlearning of the acquired organization's past practices so as to create an atmosphere for capability transfer (Haspeslagh and Jemison, 1991; Hedberg, 1981).

Drawing on findings of CEO succession studies, we suggest that when the need for integration is high, acquiring firms may encourage succession among acquired CEOs to facilitate integrative changes during related acquisitions. The argument is based on a well-established finding that CEO succession creates opportunities for organizational change (Meyer, 1978; Miller, 1993). Due to the CEO's visible position and symbolic function in maintaining organizational stability (Pfeffer, 1981), change in this top leadership position is likely to facilitate dissolution of the acquired organization's boundaries, making it easier for the acquirer to introduce suggested change. Furthermore, CEO succession can signal the beginning of a new era for the organization and may produce a symbolic motivation for members of acquired organizations to alter long-standing decision-making premises (Hedberg, 1981; Miller, 1991; Pfeffer, 1981), thereby increasing the capacity for learning new organizational practices.

Although these arguments imply that the acquiring firm may strategically force out an acquired $\mathrm{CEO}$, dismissal does not represent the only way to replace the incumbent CEO. Acquirers, for example, may act to evoke feelings of isolation among acquired CEOs, thus encouraging CEOs to resign voluntarily during acquisition (Hambrick and Cannella, 1993); or CEOs of acquired organizations may anticipate forthcoming dismissal and quit before they are fired. Whether or not the succession is voluntary or involuntary, departure of acquired CEOs creates 'a vacuum of power' that enables intervention by acquiring firms. Hence, from the acquirer's perspective, both types of succession represent an opportunity to transform and integrate a new subsidiary 


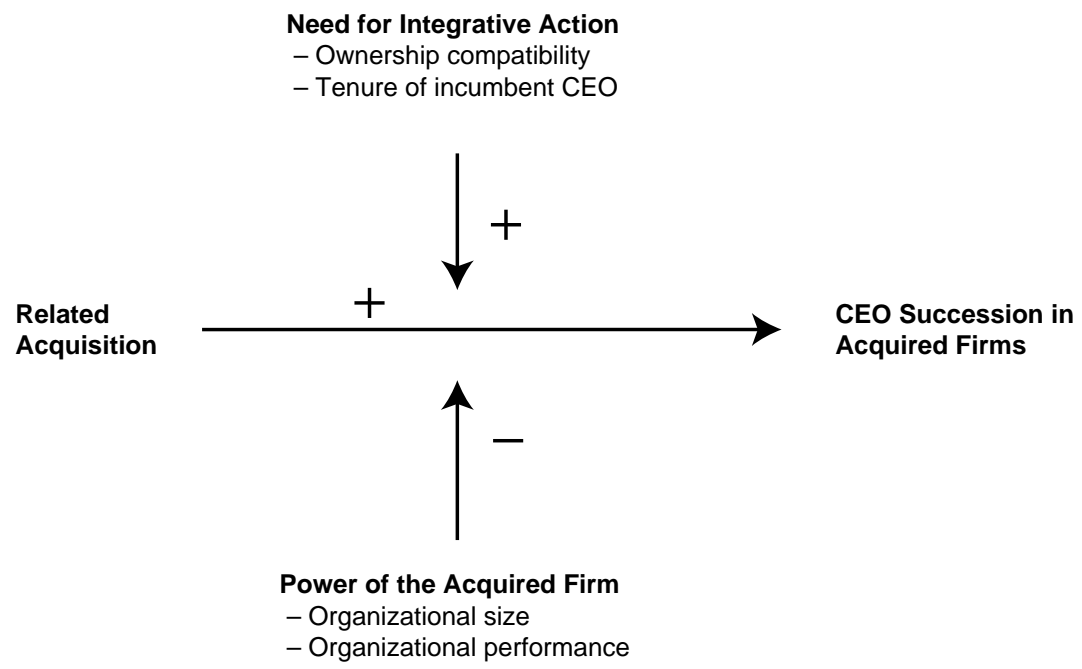

Figure 1. Model of Acquisition-induced CEO Succession

(Datta and Grant, 1990; Furtado and Karan, 1990). ${ }^{1}$

\section{Model of acquisition-induced CEO succession}

Although departure of the acquired CEO during related acquisition may be encouraged (if not subsidized outright) by the acquirer to expedite installation of corporate control, probability of CEO succession is likely to vary by specific attributes of the acquisition. Figure 1 presents a model that specifies two acquisition attributes that potentially moderate the relationship between related acquisition and CEO succession. The model suggests that succession among acquired CEOs increases as a function of the need for integrative action and decreases with the power of organizations being acquired.

\footnotetext{
1 Meaningful distinctions between voluntary (resignation) and involuntary (firing) succession are blurred in practice. Many studies have shown that CEO dismissals are rare or under-reported, mainly because the company and the CEO tend to use pre-emptory resignation as an alternative to the hardship of firing (Burda, 1988; Furtado and Karan, 1990). Even if our data permit restriction of our dependent variable to literal involuntary successions, the sample will be too small for analysis. Further, the results are likely to be biased due to the exclusion of many pre-emptory resignation cases.
}

Need for integrative action. Need for integrative action reflects the differences between firms participating in a related acquisition and the extent of effort required to transform the acquired subsidiary in accordance with the strategic goals of the acquirer. Both of these conditions affect the ability of participating firms to operate synergistically in the post-acquisition period. As such, we expect a higher likelihood of succession among acquired CEOs when organizations participating in a related acquisition differ in their organizational structure and strategy, or when suggested changes by the acquirer are likely to be hampered by established practices and values of the acquired company.

Two variables - compatibility of corporate ownership and tenure of incumbent CEO - are used to represent different dimensions of requirement for integration. Differences in corporate ownership type represent a fundamental distinction in our sample of US hospitals. Corporate ownership indicates the type of entity responsible for establishing the company's business and operational policies. Depending on ownership type (e.g. notfor-profit versus for-profit), organizations may have different goals, markets, sources of funding and institutional constraints (Alexander and Scott, 1984; Freeman and Lomi, 1994; Hollingsworth and Hollingsworth, 1987). These differences define the organization's property rights, and the 
structure and strategy for accomplishing defined goals. For example, non-profit hospitals usually enjoy relief from corporate taxation and taxdeductible gifts; they are more likely to provide care to a broader service population, rely on government support or private donations, and emphasize community services. By contrast, forprofit hospital firms tend to raise capital through equity markets. Due to pressures to grow and distribute profits to shareholders, these hospitals tend to emphasize profit maximization, use resources more efficiently and are more cost conscious (Hollingsworth and Hollingsworth, 1987).

To the extent that ownership type influences organizational strategy and decision-making frames, consolidating two firms with different ownership types will require greater effort to introduce new strategic and institutional priorities, as well as new behaviours, skills and knowledge. Therefore, we expect:

H1: Compared to acquisitions involving firms with a similar corporate ownership type, CEO succession is more likely when the ownership type of the acquired company differs from that of the acquirer.

Related acquisition and subsequent integration often require significant shifts in strategies, structures and control mechanisms. However, changes are likely to be more difficult in acquired organizations with long-tenured CEOs (Greiner and Bhambri, 1989; Miller, 1991; Tushman and Romanelli, 1985; Virany, Tushman and Romanelli, 1992). CEOs with lengthy tenure tend to emphasize existing competencies. They prefer stability and often eschew activities inconsistent with established practices (Miller, 1991). These characteristics limit the ability of the organization to change. Because changes are necessary following related acquisition, we expect greater need to integrate acquired firms managed by long-tenured CEOs. Further, as suggested previously, replacing the acquired CEO may separate the organization from its past, thereby increasing organizational members' capacity for acquiring new knowledge and practices. In this regard, departure of longtenured CEOs will be expected to have a significant impact.

A counter-argument may be proposed that CEOs with extended tenure tend to institutionalize individual power and are able to resist suggested change and replacement by the acquirer. However, it is precisely because of this tendency to withstand change that acquiring firms are more likely to encourage succession of acquired CEOs with longer tenure. Therefore, we hypothesize:

H2: Compared to their counterparts with short-tenured CEOs, acquired firms with long-tenured CEOs are more likely to experience CEO succession during related acquisition.

Power of the acquired organization. Although acquiring firms tend to assume administrative control over new subsidiaries (Cartwright and Cooper, 1993; Datta, 1991; Jemison and Sitkin, 1986), decisions regarding CEO succession in acquired firms may not be solely determined by acquirers and their desire to integrate new members. To the extent that departure of an incumbent CEO threatens the autonomy of the acquired company, CEO succession is likely to be resisted. The success of such resistance, however, depends on the power of the acquired organization. Power of the acquired organization in this context derives from organizational size and performance.

Size reflects a firm's dependence on external resources and, consequently, the degree of power and autonomy in negotiating with other companies (Pfeffer, 1982; Pfeffer and Salancik, 1978; Scott, 1992). Smaller companies tend to place greater importance on joining a multi-institutional corporation than their larger counterparts because of greater need to obtain resources or managerial support from the parent corporation (Sofaer and Myrtle, 1991). The resulting weak bargaining position may force small firms to make concessions during acquisition negotiations, thus increasing the likelihood of succession of their CEOs. By contrast, larger firms are better able to secure resources from their environments (Aldrich and Auster, 1986; Pfeffer and Salancik, 1978; Sofaer and Myrtle, 1991). This ability may accord them more power during acquisition transactions, thereby allowing them to resist attempts to replace their CEOs.

H3: Compared to their larger counterparts, smaller firms are more likely to experience CEO succession during related acquisition.

Weak negotiation power can also result when the acquired firm performs poorly. Poor performance 
places pressures on the acquired company to seek support and resources from the suitor organization and therefore limits its power to negotiate favourably during acquisition transactions (Pfeffer and Salancik, 1978; Scott, 1992). By contrast, acquired companies with high performance are less dependent on the prospective parent corporation for critical resources and thus have more power than their poor-performing counterparts during acquisition (Pfeffer and Salancik, 1978; Scott, 1992; Sofaer and Myrtle, 1991). Such performance differences among acquired firms are likely to translate into greater or less retention of existing practices and management in the acquired organization.

H4: Compared to their high-performing counterparts, poor-performing firms are more likely to experience CEO succession during related acquisition.

\section{Alternative explanations}

Rather than serving to integrate acquired organizations in the post-acquisition period, CEO succession can also be explained by other factors. Of particular concern are those that potentially explain both CEO succession and related acquisition. Variables representing these alternative explanations will be incorporated as controls in the analysis. They include organizational performance, tenure of incumbent CEO, organizational size and environmental adversity.

Performance. The relationship between performance and CEO succession has been supported by a large number of studies (e.g. James and Soref, 1981; McEachern, 1975; Salancik and Pfeffer, 1980). CEOs in high-performing firms are able to consolidate their position because of support from organizational constituencies. By contrast, when performance suffers, support for the CEO will diminish and separation is likely to result (Gamson and Scotch, 1964).

High performance may also reduce the likelihood of acquisition (Morrisey and Alexander, 1987). Because high-performing organizations have less need for resources or support from a multiinstitutional corporation, potential benefits from acquisition will be less compelling and are likely to be outweighed by preservation of organizational autonomy (Pfeffer and Salancik, 1978; Sofaer and Myrtle, 1991).
Tenure of incumbent CEO. CEOs with extended tenure are able to establish power by acquiring control of critical resources and support from important constituencies (Finkelstein, 1992; Hambrick and Fukutomi, 1991; Hill and Phan, 1991). Their power may forestall their dismissal or reduce the likelihood of their seeking more attractive positions elsewhere.

CEO tenure is also associated with the organization's ability to change (Greiner and Bhambri, 1989; Wiersema and Bantel, 1993). Organizations with long-tenured CEOs tend to be stable and resist changes that fundamentally shift organizational structure and strategy (Hill and Phan, 1991; Miller, 1991, 1993; Tushman and Romanelli, 1985). Hence, acquisition will be less likely among these organizations.

Organizational size. CEO succession will be more likely in smaller organizations in our sample. Studies in the hospital industry have shown that small hospitals tend to be stepping stones to more prestigious positions in larger organizations, whereas large hospitals represent the end point of many management careers (Alexander, Fennell and Halpern, 1993; Weil and Timmerberg, 1990).

Size also affects the likelihood of being acquired by a suitor organization. Larger organizations have greater slack resources enabling them to absorb the impact of internal and environmental disturbances (Alexander et al., 1993; Levinthal, 1994). In so far as motivation to link with other organizations is influenced by organizational difficulties, acquisition will be less attractive to larger organizations.

Environmental adversity. Adverse environments with limited carrying capacity and intense competition expose the CEO position to considerable risk and lead to high succession rates (Pfeffer and Salancik, 1977; Wiersema and Bantel, 1993). Environmental adversity also influences the level of acquisition activity. Acquisitions are less likely to occur in areas with limited demand for organizational services because of the small opportunity to exploit scale economies (Starkweather, 1981). Intense competition may also decrease economic returns to the acquirer and, consequently, the frequency of acquisition attempts in such environments (Morrisey and Alexander, 1987). 


\section{Methods}

We tested our theoretical model on the population of US community hospitals operating in 1980. Community hospitals are defined as nonfederal, short-term hospitals whose services are available to the public (American Hospital Association, 1991). They form a large class of organizations. In 1980, there were 5956 community hospitals, providing services accounting for about $40 \%$ of total US health-care expenses.

Our model applies to related acquisition in which suitor and acquired organizations share similar products and/or operate in the same market. We tested the model with one form of related acquisition prevailing in the health-care sector: acquisition of hospitals by multi-hospital systems (MHSs). Although MHSs may expand through acquisitions into areas such as long-term care, outpatient surgery, managed care, clinical laboratory, medical equipment and health insurance (Finkler and Horowitz, 1985), the major business of MHSs, as well as hospitals, is to provide inpatient care. Such commonalities of product, market and technology suggest that MHS acquisition of hospitals represents a useful case for testing our hypotheses.

MHS acquisition means the transfer of the control of a free-standing hospital to a corporately structured health-delivery system that operates two or more hospitals (Alexander, 1991; Shortell, 1988). Acquisitions are achieved through negotiations between participating organizations and do not result in dissolution of the acquired hospital (Wegmiller, 1985). Hospitals in a system retain a structure and operation similar to an independent hospital, have a CEO and, in some cases, a local governing board responsible for making policy and strategic decisions in response to requirements in the local market. But the MHS retains final decision-making authority over major strategic and fiscal issues and evaluates the performance of the hospital.

Recent years have seen tremendous growth in MHS acquisitions and an increased emphasis on system integration (Shortell, 1988). The development of MHSs is shaped primarily by the intense competition in the health-care industry and, particularly, the introduction of the Medicare Prospective Payment System (PPS) in 1983 (Shortell, 1988). PPS altered the way Medicare paid for hospital care from a cost-based reimbursement system to a prospective per case system based on the diagnosis of the patient. Under this system, hospital inpatient services are paid with one fee set in advance and hospitals have to bear any costs exceeding the pre-set rate (Office of Technology Assessment, 1985). Since Medicare beneficiaries constitute the major group of hospital patients, such regulatory change has also forced MHSs to become more efficient and cost conscious and to actively explore advantages of scale economies (Finkler and Horowitz, 1985). Such economic motivations have increased the emphasis on unification or 'systemness' and encouraged integration of services and organizational operations among subsidiary hospitals (Shortell, 1988).

\section{Data}

Data are obtained from four sources: the American Hospital Association (AHA) Annual Hospital Surveys, 1980-88; the Area Resource File; the AHA MHS validation file; and 1984-88 AHA Hospital Guides Part B: Multihospital systems. The Annual Surveys contain information on hospital characteristics, facilities and services, expenses and personnel, and inpatient beds and utilization. The Area Resource File is a compilation of health and population characteristics specified at the county level. The MHS validation file was created by the AHA as an inventory of all MHSs and their subsidiary hospitals as of 1983. It contains information on system ownership and the year each hospital was acquired by the system. Information on MHS acquisition after 1983 is abstracted from Part B of AHA Hospital Guides.

Data from these sources are merged to construct a data set that consists of annual, repeated observations for all community hospitals operating in 1980 until the end of the study period or the year of censoring. Censoring is defined as hospital closure or dissolution as a result of merger during the study period. Because the effects of predicting variables (except for MHS acquisition) on CEO succession are unlikely to be instantaneous and to enhance causal explanation, predictors are lagged by one year. The study covers an eight-year period (1981-88) and involves 43474 observations.

\section{Measurement}

CEO succession. CEO succession is the change in hospital CEO in consecutive years, coded ' 1 ' 
when a change occurs, and ' 0 ' otherwise. We do not differentiate between voluntary and involuntary departure of CEOs. Both types of succession represent a major event significantly influencing an organization's subsequent performance and strategic direction (Furtado and Karan, 1990). Other than terminations caused by death and illness which are likely to be dispersed randomly among sample hospitals, both voluntary and involuntary turnovers provide corporate headquarters an opportunity to restructure and integrate the newly acquired hospital.

Related acquisition. This is represented by MHS acquisition of a hospital, defined as (1) change from an independent hospital to a subsidiary of a MHS, or (2) change of hospital control from one system to another. The latter could occur if the hospital was divested by one system and subsequently acquired by another during the study period. In the case of consecutive MHS acquisitions (117 such events over the study period), each acquisition is treated as a separate, independent event because each acquisition may require integrating the acquired hospital to achieve synergy. ${ }^{2}$

Ownership type and compatibility of corporate ownership. Based on the type of the controlling entity, hospitals and multi-hospital systems are classified into not-for-profit and for-profit (investorowned) categories. Compatibility of corporate ownership is defined as the situation in which an acquisition involves a hospital and a system with the same ownership type. Compatible corporate ownership is coded ' 1 ,' and ' 0 ' otherwise.

Tenure of incumbent CEO. CEO tenure is the number of years since the most recent CEO succession in the acquired organization.

Organizational size. Organizational size is measured by the number of beds set up and staffed by the hospital.

\footnotetext{
2 Separate analyses including and excluding multiple acquisitions were performed to evaluate the impact of including these events. The results are essentially identical, with minute differences at the third or fourth decimal place of the estimated coefficients and standard errors. On this basis, we chose to include all acquisitions in the analysis.
}

Performance. Performance is measured by two variables: occupancy and total expenses per adjusted inpatient day. Occupancy is the ratio of average daily census to statistical beds. It measures the degree to which the hospital effectively utilizes its production capacity (Griffith, 1987). If occupancy is too low, increased fixed costs will threaten hospital viability. Occupancy also reflects a hospital's ability to market its services and appropriately staff its bed stock (Goodstein and Boeker, 1991; Morrisey and Alexander, 1987). It is a widely used performance measure. For investor-owned hospitals that operate as profit maximizers, occupancy is a major determinant of financial performance. For not-for-profit hospitals, it indicates the hospital's ability to satisfy the needs of its service population.

Total expenses per adjusted inpatient day capture hospital operating efficiency. Efficiency is defined as the ratio of an organization's input to output (Ehreth, 1994; Sherman, 1984). Higher efficiency means greater output produced with the same amount of input, or the same amount of output produced with less input (i.e. lower ratio of total expenses to adjusted inpatient days). Hospital average length of stay is included in the model to account for the severity level of patients treated in the hospital and its effect on total expenses.

Environmental adversity. Several variables are used to indicate the level of adversity in a hospital's market. First, per capita income measures the local population's average ability to purchase hospital services. Second, the number of physicians per 1000 population measures demand for hospital services based on the fact that physicians, acting as purchasing agents on patients' behalf, are key consumers of hospital services. Finally, the number of community hospital beds per 1000 population is used to represent the level of market competition. High environmental adversity is represented by low per capita income, low physician density and a large supply of hospital beds.

Other control variables. We include three additional determinants of CEO succession in the models: contract management, secular trend and tenure as a system hospital.

1 Contract management. Under management contract, an external management company 
provides a top management team and other support services for the hospital (Alexander, 1991). By definition, contracting leads to succession of the incumbent CEO. We assign ' 1 ' to hospitals experiencing a change in the status of contract management, and ' 0 ' otherwise.

2 Secular trend/period effect. We expect a secular trend in hospital CEO succession in view of the introduction of Medicare PPS in 1983. The change and uncertainty associated with Medicare PPS placed hospital CEOs at increased risk (Wiersema and Bantel, 1993). As such, higher rates of CEO succession may occur after 1983. To assess this secular trend, we specify the study period as an interval variable with values ranging from 1 to 8 .

3 Hospital tenure in system. CEOs in system hospitals have higher turnover than their freestanding counterparts because of the corporate practice of management rotation and promotion within the MHS (Alexander et al., 1993; Weil, 1990). This difference is controlled by including the number of years since acquisition by an MHS in the analysis.

\section{Analysis}

Our hypotheses are tested with discrete-time event history analysis (logit modelling). The logit model is appropriate for observations with a sequence of binary responses and for data recording the particular interval of time (e.g. year) in which each event occurs (Allison, 1984; Yamaguchi, 1991). The model takes into account rightcensored observations and is able to deal with a large number of ties without introducing bias in parameter estimation (Allison, 1984; Yamaguchi, 1991).

Logit modelling estimates the conditional probability that a hospital experiences CEO succession at a particular time period given that the CEO remains in office to the beginning of the period and is at risk for succession. The simple format of a logit model is

$$
\ln \left[\frac{\lambda\left(t_{i} ; x\right)}{1-\lambda\left(t_{i} ; x\right)}\right]=a+\Sigma_{k} b_{k} x_{k}
$$

Where $\lambda\left(t_{i} ; x\right)$ is the conditional probability that a hospital experiences CEO succession at $t_{i}, x_{k}$ is the covariate, and $b_{k}$ is the estimated parameter (Yamaguchi, 1991).

The analysis involves multiple observations of the same hospitals over time. Because these repeated observations may be auto-correlated, standard logit models may yield artificially small standard-error estimates and lead to overestimation of statistical significance (Hannan and Young, 1977; Zeger and Liang, 1992). We use generalized estimating equations (GEEs) to model our correlated data (Zeger and Liang, 1992). GEEs treat auto-correlation as a nuisance and estimate it separately from the estimation of regression coefficients. This approach generates consistent estimates of parameters under minimal assumptions of the correlation pattern.

Analysis of pooled, repeated observations assumes that the effects of covariates are timeindependent (Hannan and Young, 1977). We test this assumption by incorporating interactions between time (years) and predicting variables in the model. All interactions are non-significant except for contract management. To account for this time-variant effect, an interaction term between time and contract management is added to the logit models.

Finally, we evaluated the appropriate form of period effects and hospital tenure in a MHS. Results suggest that second-order, non-linear relationships best approximate the effects of these two variables on CEO succession. Hence, quadratic forms of these variables are included in the models.

\section{Results}

A total of 755 MHS acquisitions occurred from 1981-88, representing an average acquisition rate of $1.65 \%$. The average CEO succession rate was $19.7 \%$ during this period. A rapid increase in CEO succession was observed after the establishment of Medicare PPS in 1983; the succession rate reached a peak of $22.6 \%$ in 1987 and then decreased to $19.5 \%$ in 1988 .

Table 1 presents means, standard deviations and Pearson correlations for all study variables. Correlations should be interpreted cautiously because their significance levels tend to be inflated by repeated observations (Hannan and Young, 1977). 


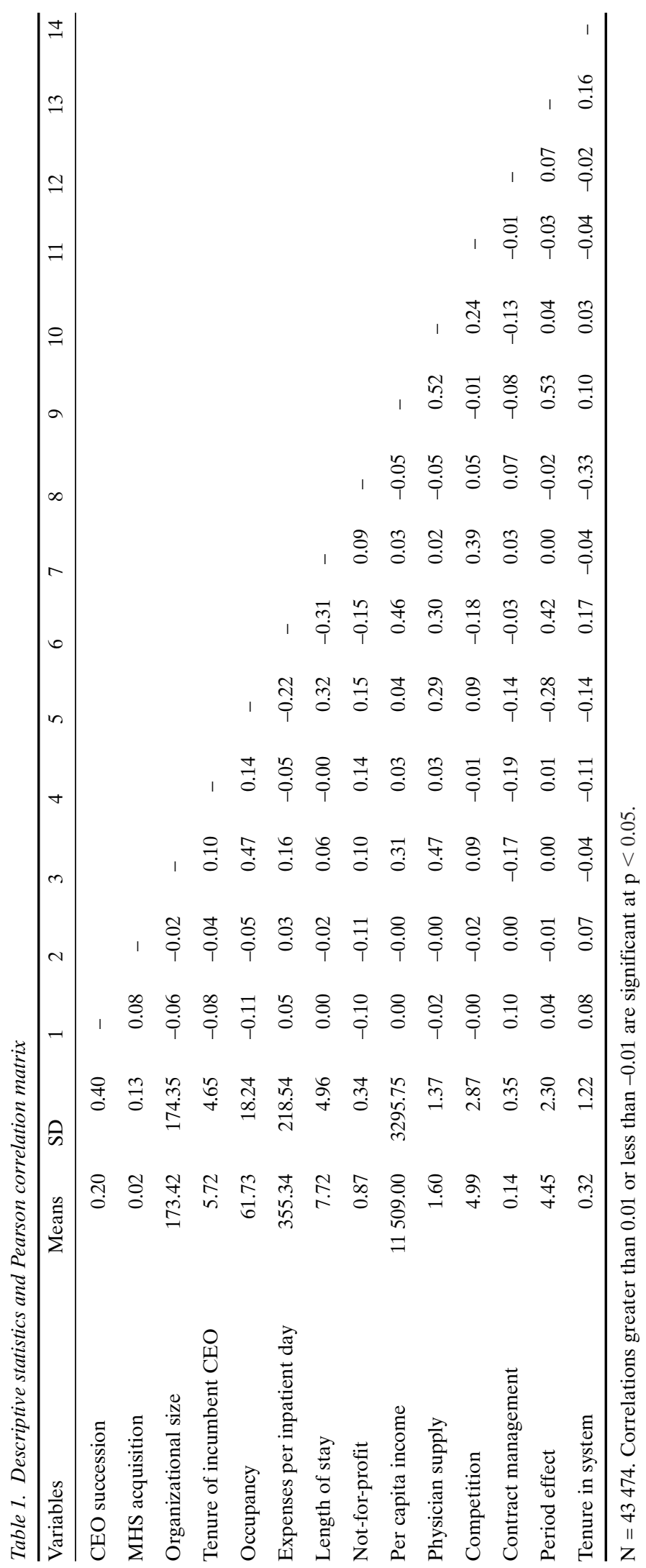


Table 2. Results of discrete-time logit models: the effect of compatibility of corporate ownership on CEO succession ${ }^{\mathrm{a}}$

\begin{tabular}{|c|c|c|c|c|}
\hline \multirow[b]{2}{*}{ Variables } & \multicolumn{2}{|l|}{ Model 1} & \multicolumn{2}{|l|}{ Model 2} \\
\hline & $\beta$ & se & $\beta$ & se \\
\hline Intercept & $2.49 * * *$ & 0.61 & $2.73 * * *$ & 0.62 \\
\hline $\begin{array}{l}\text { Control variables } \\
\text { Organizational size } \\
\text { Tenure of incumbent CEO } \\
\text { Occupancy rate } \\
\text { Total expenses per inpatient day } \\
\text { Length of stay } \\
\text { Non-profit ownership } \\
\text { Per capita income } \\
\text { Physician supply } \\
\text { Competition } \\
\text { Period effect } \\
\text { (Period effect) }^{2 c}\end{array}$ & $\begin{array}{l}-0.02 \mathrm{E}-1 * \mathrm{~b} \\
0.03 \dagger \\
-0.02^{* * *} \\
0.07 \mathrm{E}-2 \\
0.06^{*} \\
-0.21 \\
-0.01 \mathrm{E}-2 * * \\
0.13 \\
-0.08 \dagger \\
-0.01 \\
-0.06^{* * *}\end{array}$ & $\begin{array}{l}0.01 E-1 \\
0.02 \\
0.06 E-1 \\
0.01 E-1 \\
0.02 \\
0.18 \\
0.00 \\
0.12 \\
0.04 \\
0.04 \\
0.02\end{array}$ & $\begin{array}{l}-0.02 \mathrm{E}-1 * \\
0.04 \dagger \\
-0.02 * * * \\
0.07 \mathrm{E}-2 \\
0.06^{*} \\
-0.36 \dagger \\
-0.01 \mathrm{E}-2 * * \\
0.10 \\
-0.07 \dagger \\
-0.01 \\
-0.06^{* * *}\end{array}$ & $\begin{array}{l}0.01 \mathrm{E}-1 \\
0.02 \\
0.06 \mathrm{E}-1 \\
0.01 \mathrm{E}-1 \\
0.02 \\
0.20 \\
0.00 \\
0.12 \\
0.04 \\
0.04 \\
0.02\end{array}$ \\
\hline Compatibility of ownership & & & $0.40 \dagger$ & 0.21 \\
\hline $\begin{array}{l}\text { Likelihood-ratio chi-square, } \mathrm{L}^{2}(\mathrm{df})^{\mathrm{d}} \\
\text { G versus Model } 1 \text { (df) }\end{array}$ & $86.85(11)^{* * *}$ & & $\begin{array}{l}90.93(12)^{* * *} \\
4.08^{*}\end{array}$ & \\
\hline
\end{tabular}

Notes:

${ }^{a} \mathrm{n}=717$. Unstandardized regression coefficients are reported.

${ }^{\mathrm{b}} \mathrm{E}-\mathrm{a}=10^{-\mathrm{a}}$.

c Variables are centred $(X-\bar{X})$ to reduce the potential bias caused by multi-collinearity (Cronbach, 1987).

${ }^{\mathrm{d}}$ Obtained from the SAS PROC LOGISTIC procedure.

$\dagger \mathrm{p}<0.10$.

$* \mathrm{p}<0.05$.

$* * \mathrm{p}<0.01$.

$* * * \mathrm{p}<0.001$

\section{Hypothesis testing}

Our hypotheses are tested in a series of hierarchical logit models. The baseline model includes control variables and a term representing MHS acquisition. Hypotheses are tested by adding variables representing each hypothesis to the baseline model.

$\mathrm{H} 1$ suggested that $\mathrm{CEO}$ succession would be more likely when ownership of the acquired organization differed from that of the acquirer. This hypothesis was tested using a sub-sample of hospitals newly acquired by multi-hospital systems during the study period, and by adding compatibility of corporate ownership to the baseline model. Because there was no variation on tenure in MHS and contract management (contract management and MHS acquisition are mutually exclusive) in the first year of acquisition, these two variables were omitted from the model.

Results reported in Table 2 support H1. Compatibility of corporate ownership displays a significant, negative relationship with CEO succession during acquisition. The change in likelihood-ratio chi-square $(\mathrm{G}=4.08, \mathrm{p}<0.05)$ shows that including compatibility of corporate ownership significantly improves the fit of the model. Based on the estimated coefficient, compatible corporate ownership type reduces the likelihood of CEO succession by $33 \%$ (odds ratio $=0.67$ ).

Tests of H2-4 used the whole sample of hospitals and involved the interactions between MHS acquisition and three contingency variables - CEO tenure, size and performance. Results are presented in Model 2 of Table 3. Overall, incorporating the interaction terms improves the explanatory power of the model, as indicated by the difference in likelihood-ratio chi-square $(\mathrm{G}=30.5$, $\mathrm{p}<0.001)$.

$\mathrm{H} 2$ posited that organizations with longer $\mathrm{CEO}$ tenure would be at higher risk for succession during related acquisition compared with their counterparts with shorter tenure, because there is greater need for integrative action. This expectation is supported by the significant and positive interaction between CEO tenure and succession. 
Table 3. Results of discrete-time logit models: effects of related acquisition and contingency variables on CEO succession ${ }^{\mathrm{a}}$

\begin{tabular}{|c|c|c|c|c|}
\hline \multirow[b]{2}{*}{ Variables } & \multicolumn{2}{|l|}{ Model 1} & \multicolumn{2}{|l|}{ Model 2} \\
\hline & $\beta$ & se & $\beta$ & se \\
\hline Intercept & $-0.46 * * *$ & 0.10 & $-1.24 * * *$ & 0.08 \\
\hline \multicolumn{5}{|l|}{ Control variables } \\
\hline Organizational size & $-0.04 \mathrm{E}-3^{\mathrm{b}}$ & 0.00 & $-0.08 \mathrm{E}-3$ & 0.00 \\
\hline Tenure of incumbent CEO & $-0.02 * * *$ & $0.03 \mathrm{E}-1$ & $-0.02 * * *$ & $0.03 \mathrm{E}-1$ \\
\hline Occupancy rate & $-0.01 * * *$ & $0.01 \mathrm{E}-1$ & $-0.01 * * *$ & $0.01 \mathrm{E}-1$ \\
\hline Total expenses per inpatient day & $0.03 \mathrm{E}-2 \dagger$ & 0.00 & $0.03 E-2 \dagger$ & 0.00 \\
\hline Length of stay & $0.02 * * *$ & $0.03 \mathrm{E}-1$ & $0.02 * * *$ & $0.03 \mathrm{E}-1$ \\
\hline Non-profit ownership & $-0.47 * * *$ & 0.04 & $-0.47 * * *$ & 0.04 \\
\hline Per capita income & $-0.02 \mathrm{E}-4$ & 0.00 & $-0.02 \mathrm{E}-4$ & 0.00 \\
\hline Physician supply & 0.02 & 0.02 & 0.02 & 0.02 \\
\hline Competition & $0.04 \mathrm{E}-2$ & $0.05 \mathrm{E}-1$ & $0.02 \mathrm{E}-2$ & $0.05 \mathrm{E}-1$ \\
\hline Contract management & $0.62 * * *$ & 0.03 & $0.62 * * *$ & 0.03 \\
\hline Period effect & $0.06 \mathrm{E}-1$ & 0.01 & $0.05 \mathrm{E}-1$ & 0.01 \\
\hline$(\text { Period effect })^{2 c}$ & $-0.01 * * *$ & $0.03 \mathrm{E}-1$ & $-0.01 * * *$ & $0.03 \mathrm{E}-1$ \\
\hline Tenure in system & $0.18 * * *$ & 0.03 & $0.18 * * *$ & 0.03 \\
\hline$(\text { Tenure in system })^{2 c}$ & $-0.02 * * *$ & $0.04 \mathrm{E}-1$ & $-0.02 * * *$ & $0.04 \mathrm{E}-1$ \\
\hline$(\text { Contract management })^{*}(\text { time })^{c}$ & $-0.06^{* * *}$ & 0.01 & $-0.06 * * *$ & 0.01 \\
\hline MHS acquisition & $0.83 * * *$ & 0.08 & $0.75^{* * *}$ & 0.10 \\
\hline \multicolumn{5}{|l|}{ Contingency variables } \\
\hline$($ Acquisition $) \times(\text { CEO tenure })^{c}$ & & & $0.06 * *$ & 0.02 \\
\hline$($ Acquisition $) \times(\text { size })^{c}$ & & & $-0.03 \mathrm{E}-1 * *$ & $0.01 \mathrm{E}-1$ \\
\hline$($ Acquisition $) \times(\text { occupancy rate })^{c}$ & & & $-0.09 \mathrm{E}-1$ & $0.05 \mathrm{E}-1$ \\
\hline$($ Acquisition $) \times(\text { operational efficiency })^{c}$ & & & $-0.02 \mathrm{E}-2$ & 0.00 \\
\hline Likelihood-ratio chi-square, $\mathrm{L}^{2}(\mathrm{df})^{\mathrm{d}}$ & $1612.89(16)^{* * *}$ & & $1643.39(20)^{* * *}$ & \\
\hline G versus Model 1 (df) & & & $30.50(4) * * *$ & \\
\hline
\end{tabular}

\section{Notes:}

${ }^{\mathrm{a}} \mathrm{n}=43$ 474. Unstandardized regression coefficients are reported.

${ }^{\mathrm{b}} \mathrm{E}-\mathrm{a}=10^{-\mathrm{a}}$.

${ }^{\mathrm{c}}$ Variables are centred $(X-\bar{X})$ to reduce the potential bias caused by multi-collinearity (Cronbach, 1987).

${ }^{\mathrm{d}}$ Obtained from the SAS PROC LOGISTIC procedure.

$\dagger \mathrm{p}<0.10$.

$* \mathrm{p}<0.05$.

$* * \mathrm{p}<0.01$.

$* * * \mathrm{p}<0.001$

The finding indicates that every year of increase in CEO tenure increases the likelihood of succession during acquisition by $4 \%$ (odds ratio $=1.04)$.

H3 stated that succession during related acquisition would be more likely if the acquired organization was smaller in scale, because smaller organizations had less power during acquisition negotiations. This prediction is supported by the significant and negative interaction between size and MHS acquisition. To illustrate, an increase of 100 beds reduces the likelihood of CEO succession during acquisition by $27 \%$ (odds ratio $=0.73$ ).

$\mathrm{H} 4$ predicted that during related acquisition, organizations with poorer performance are more likely to experience CEO succession than those with better performance. The hypothesis is not supported by the analysis. Neither of the two interactions terms involving performance is statistically significant.

\section{Effects of control variables}

With few exceptions, effects of control variables are consistent with our expectations. Similar to previous studies on for-profit companies (Furtado and Karan, 1990; Hambrick and Cannella, 1993; Martin and McConnell, 1991; Walsh, 1988, 1989; Walsh and Ellwood, 1991; Walsh and Kosnik, 1993), related acquisition significantly increases the likelihood of CEO succession. In general, succession is less likely to occur among CEOs with longer 
tenure. High performance (high occupancy and low total expenses) reduces the likelihood of succession among hospital CEOs. But CEOs are more likely to leave when the hospital is managed under contract by a separate firm. Not-for-profit hospitals and those with longer length of stay also experience higher rates of succession. No significant associations are found between CEO succession and organizational size, market capacity and competition in the model.

During the study period, rate of CEO succession in the study group exhibits a curvilinear secular pattern. It first increases and then declines in the later years of the period. A similar succession pattern occurs among CEOs of system hospitals. According to the quadratic expression of the system tenure variable, CEO succession increases gradually after the hospital is acquired by a MHS, but then declines after a period.

A variant of split-half validation was performed to examine the reliability of findings for Model 2 (Kleinbaum, Kupper and Muller, 1988). We randomly assigned our sample into two groups and re-analysed the logit model for each sub-sample. Except for changes in the sign of the coefficients on competition and period effect, comparisons of results for the entire sample and the two subsamples reveal only minor differences. None of these differences, however, changes the substantive interpretation of our results.

\section{Discussion}

Our argument that CEO succession functions as an integrative mechanism is corroborated by support for our contingency hypotheses. If succession among acquired CEOs is driven, at least in part, by the intent to integrate a newly acquired subsidiary, the probability of succession is expected to be higher when participating firms have incompatible ownership that inhibits capability transfer, or when the acquired organization has a longtenured CEO which reduces its ability to change. Both hypotheses are supported in the analysis.

In most consolidation transactions, acquiring organizations tend to dictate policy, control strategic scenarios and expect quick return on their investment (Cartwright and Cooper, 1993; Datta, 1991; Datta and Grant, 1990). Their policies and desired changes, however, may be ignored if not backed up by implementation efforts (Mintzberg,
1983). Thus, a new CEO may be brought in to represent the acquirer and ensure that required changes are effectively carried out by the new subsidiary. In this way, succession of acquired CEOs not only serves as a control function but may enhance the standardization of corporate practices. Such standardization may, in turn, enhance the cooperation among units of the multidivisional corporation and increase the realization of synergistic benefits.

Further, succession of acquired CEOs may have a symbolic function during periods of profound organizational change (Pfeffer, 1981). 'Ceremonies of firing and replacement can help to ... signal changes in policies and practices to those who work within the organization. Such ceremonies are an important part of the management and creation of organizational belief systems' (p. 40). Replacing the incumbent CEO with someone hired by the acquirer also signifies the acquisition to constituencies of the participating organizations. Such 'mutual' identification may lead to 'expectations and labelling effects that serve to reinforce the association between the organizations' (Pfeffer, 1981, p. 35), particularly when the acquisition occurs between two companies with distinct orientations, policies and behaviours.

We also posited that attempts to change the acquired CEO are more likely to be resisted successfully when the acquired organization has more power due to larger scale or stronger performance. Results show that larger acquired organizations experience lower risk of CEO succession during the transaction of related acquisition. Performance, however, has no effect on post-acquisition CEO succession.

Considering post-acquisition CEO succession as a response of acquired firms to external constraints, our finding that large organizational scale reduces likelihood of CEO succession renders support to resource dependency theory. According to the theory, inter-organizational power is determined by the degree to which the focal organization relies on others for critical resources (Pfeffer, 1982; Pfeffer and Salancik, 1978). The more an organization depends on outside resources, the more it conforms to demands of external groups that control those resources. Because larger organizations are better able to secure resources and are more selfsufficient, they may have more power to resist 
control and requirements imposed by the acquiring corporation.

The finding that performance has no contingent effect on CEO succession undermines the notion that acquisition is an efficiency-enhancing mechanism to remove ineffective management of target companies and therefore improve industrywide economic productivity (Varian, 1988). In fact, as Walsh and Kosnik (1993) suggest, this argument may be used by some acquirers as an 'ideological cover' for their own self-serving activities.

Together with prior studies (e.g. Furtado and Karan, 1990; Walsh and Kosnik, 1993), our finding that related acquisition significantly increases CEO succession may have two important implications for CEO turnover research. First, researchers have long argued that CEO succession affects change in organizational strategy (Meyer, 1978). Strategic choices and organizational change should be, in part, predicted by tenure of the top executive. Our results indicate that changes in organizational strategy can also affect CEO succession. This reverse causality helps construct a more complete picture of the dynamics between CEO succession and organizational change.

Second, most research assumes that CEO succession is determined primarily by intraorganizational factors and individual characteristics of the CEO (Fredrickson, Hambrick and Baumrin, 1988). Few studies have explored how changes in inter-organizational relationships affect CEO succession. If acquisition continues to spread over a wider range of industries or as firms increase cooperation with other organizations in response to a hyper-competitive environment (D'Aveni, 1994), more studies will be needed to understand the relationship between interorganizational activities and the political and institutional arrangements associated with executive succession.

\section{Caveats}

Several methodological issues are worth noting. First, despite the conceptual discussion of voluntary versus involuntary CEO succession in the theory section, we recognize that whether related acquisition affects voluntary and involuntary CEO succession is also an empirical issue in our study. Failure to accurately distinguish these two types of succession may represent a potential problem in our analysis. ${ }^{3}$ This potential measurement problem, however, is likely to make our results conservative, given that 'true' voluntary turnover among acquired CEOs may not be explained by our predictor variables.

Second, we use corporate ownership type to measure compatibility between participating companies because ownership frames organizational goals and strategies among organizations in the health-care industry (Hollingsworth and Hollingsworth, 1987). However, there may be other variables (e.g. marketing strategies) that affect organizational compatibility and therefore condition the risk of succession among acquired CEOs. These fine-grained distinctions are not available in our large-scale surveys and archival data sets, but should be considered in future research.

Third, information about the age of acquired CEOs may be needed to reduce the potential confounding in assessing the interactive effect of tenure and related acquisition on CEO turnover (H2). It is possible that acquired organizations led by CEOs with longer tenure are more likely to experience CEO succession because long-tenured CEOs are closer to retirement age. Therefore, we would expect a positive effect of tenure on CEO succession. This alternative expectation, however, is not supported by the negative and significant coefficient of CEO tenure in our analysis.

Finally, limited variability in performance among acquired organizations may account for the absence of the moderating effects of performance on the relationship between related acquisition and CEO succession. That is, hospital acquisitions may be over-represented among organizations

\footnotetext{
3 If voluntary succession is high and if it is associated with acquisition, our results might demonstrate more the free career choice of CEOs than policies of acquiring corporations. Unfortunately, we do not have reliable sources of data on the extent of voluntary CEO succession. However, a significant relationship between related acquisition and CEO succession occurring a year after acquisition, which was likely to be voluntary, will suggest potential bias in our findings. (We are thankful to a reviewer for this suggestion.) An analysis was performed with one-year lagged related acquisition. Results showed that lagged MHS acquisition was not statistically significant in predicting CEO succession. In other words, the impact of related acquisition on voluntary CEO succession was limited, supporting our argument that $\mathrm{CEO}$ succession at the time of related acquisition might be the result of acquirers' intention to integrate acquired organizations.
} 
with either very high or very low performance records. Acquiring organizations may seek underperformers with the expectation that performance improvement may be more dramatic under system auspices. Alternatively, positive performers may be targeted for acquisition if the system intends to increase profitability from the activities of an increased number of high-performing organizations.

\section{Future research}

Overall, our model of acquisition-induced CEO succession received strong support from the data. The usefulness of our model, however, can only be improved by testing it with a greater variety of data (King, Keohane and Verba, 1994). In addition to the measurement issues discussed above, several matters are worth examination in future research.

First, our hypotheses were based on the premise that CEO succession functions to integrate newly acquired subsidiaries. From there, we predicted the likelihood of CEO succession would be conditional on need for integration and relative power of the acquired organization. Although our predictions were mostly supported by secondary data, primary information on the reasons for CEO replacement and observations of the power dynamics between partner organizations and their influence on the management structure of acquired organizations would provide the basis for more direct tests of our theory. If CEO succession is driven by integration, and therefore for functional and symbolic concerns, we are likely to observe: (1) a new CEO with prior affiliation with the acquirer or who is familiar with the corporate practices of the acquiring company; (2) a publicized ceremony of succession to signal the arrival of a new corporate era; and (3) increased changes in the subsidiary organization following related acquisition. These expectations can be verified with information on the new CEO's background, direct observation of the acquisition transition process, interviews with members of the participating organizations and structural and strategic changes in the newly acquired subsidiary.

CEO succession in newly acquired organizations may also be affected by factors such as the control span (number of subsidiaries controlled by the corporate head office) and geographic dispersion of the acquiring corporation. Larger control span, for example, may limit the ability of corporate headquarters to replace CEOs in new subsidiaries simply because fewer qualified managers are readily available (Kitching, 1967). Such limitations may require retaining the incumbent $\mathrm{CEO}$ and granting new subsidiaries relatively high autonomy (at least temporarily).

Moreover, the integration mechanism discussed in this paper is primarily concerned with related acquisitions whose purpose is to gain operating synergy by combining independent organizations. Generalization of the arguments and findings to other types of acquisitions, such as conglomerates that involve organizations with unrelated product lines (Ansoff and Weston, 1962), should be exercised with caution. Conglomerates may need to concern themselves with over- rather than undercontrol of subsidiaries, respecting the boundaries of acquired organizations, and selectively changing the new subsidiaries without harming their existing strengths. Ansoff and Weston (1962) suggest:

'[if] the merged companies have been operating in hitherto highly diverse areas, there may be little carryover of operational compatibility. Operations with only general policy or control through financial targets may be all that is necessary. To do more may impede the effective decision-making processes of the operating units.' (p. 56)

Even integration in related acquisitions should be designed and implemented within an overarching strategic framework. If the objective of acquisition is to develop strategic strengths through preservation of existing competencies, care should be exercised to preserve the distinctive strengths of the acquired organization. If the objective is joint operation, stronger intervention may be necessary (Datta, 1991; Datta and Grant, 1990; Harrison et al., 1991). Thus, future research may test if integration mechanisms such as CEO succession are used differentially in different types of acquisition (i.e. related versus unrelated acquisitions).

\section{Conclusion}

CEO succession in acquired organizations may carry with it unintended, adverse consequences. In this study, we view CEO succession as the result of rational choices made by acquiring 
companies. But, as March and Simon (1993) suggest, '[r]ationality does not assure intelligence' (p. 305). Replacing CEOs in acquired companies, for example, may cause the acquirers to be viewed as invading enemies. Widespread distrust of new leadership, increased stress and lower satisfaction and productivity among members of acquired companies may result. Even without such animosity, two consequential changes (acquisition and CEO succession) within a condensed period of time may destabilize the acquired organization to such an extent that its performance suffers. Clear understanding of such potential consequences and the conditions under which they are likely to occur can assist acquiring companies in maintaining organization morale and performance, thereby realizing anticipated synergistic economies.

\section{References}

Aldrich, H. and E. R. Auster (1986). 'Even Dwarfs Started Small: Liabilities of Age and Size and Their Strategic Implications'. In: L. L. Cummings and B. M. Staw (eds), Research in Organizational Behavior, Vol. 8, pp. 165-198. JAI Press, Greenwich, CT.

Alexander, J. A. (1991). 'Adaptive Change in Corporate Control Practices', Academy of Management Journal, 34, pp. 162-193.

Alexander, J. A. and W. R. Scott (1984). 'The Impact of Regulation on the Administrative Structure of Hospitals: Toward an Analytic Framework', Hospital and Health Services Administration, 29(3), pp. 71-85.

Alexander, J. A., M. L. Fennell and M. T. Halpern (1993). 'Leadership Instability in Hospitals: the Influence of BoardCEO Relations and Organizational Growth and Decline', Administrative Science Quarterly, 38, pp. 74-99.

Allison, P. D. (1984). Event History Analysis: Regression for Longitudinal Event Data. Sage, Newbury Park, CA.

American Hospital Association (1991). Hospital Closure 1980-1990: a Statistical Profile. American Hospital Association, Chicago.

Ansoff, H. I. and J. F. Weston (1962). 'Merger Objectives and Organization Structure', Quarterly Review of Economics and Business, 2(3), pp. 49-55.

Buono, A. F., J. L. Bowditch and J. W. Lewis (1985). 'When Cultures Collide: the Anatomy of a Merger', Human Relations, 38, pp. 477-500.

Burda, D. (1988). 'High Rate of CEO Turnover at Hospitals has Industry Scrambling to Find Out Why', Modern Healthcare, 18(22), pp. 120-121.

Cartwright, S. and C. L. Cooper (1993). 'The Role of Culture Compatibility in Successful Organizational Marriage', Academy of Management Executive, 7(2), pp. 57-70.

Chatterjee, S. (1992). 'Sources of Value in Takeovers: Synergy or Restructuring - Implications for Target and Bidder Firms', Strategic Management Journal, 13, pp. 267-286.
Cronbach, L. J. (1987). 'Statistical Tests for Moderator Variables: Flaws in Analysis Recently Proposed', Psychological Bulletin, 87, pp. 51-57.

Datta, D. K. (1991). 'Organizational Fit and Acquisition Performance: Effects of Post-acquisition Integration', Strategic Management Journal, 12, pp. 281-197.

Datta, D. K. and J. H. Grant (1990). 'Relationships Between Type of Acquisition, the Autonomy Given to the Acquired Firm, and Acquisition Success: an Empirical Analysis', Journal of Management, 16, pp. 29-44.

D'Aveni, R. A. (1994). Hypercompetition. Free Press, New York.

Ehreth, J. L. (1994). 'The Development and Evaluation of Hospital Performance Measures for Policy Analysis', Medical Care, 32, pp. 568-587.

Fairburn, J. A. and P. Geroski (1989). 'The Empirical Analysis of Market Structure and Performance'. In: J. A. Fairburn and J. A. Kay (eds), Mergers and Merger Policy. Oxford University Press, New York.

Finkelstein, S. (1992). 'Power in Top Management Teams: Dimensions, Measurement, and Validation', Academy of Management Journal, 35, pp. 505-553.

Finkler, S. A. and S. L. Horowitz (1985). 'Merger and Consolidation: an Overview of Activity in Healthcare Organizations', Healthcare Financial Management, 39(1), pp. 19-28.

Fredrickson, J. W., D. C. Hambrick and S. Baumrin (1988). 'A Model of CEO Dismissal', Academy of Management Review, 13, pp. 255-270.

Freeman, J. and A. Lomi (1994). 'Resource Partitioning and Foundings of Banking Cooperatives in Italy'. In: J. A. C. Baum and J. V. Singh (eds), Evolutionary Dynamics of Organizations, pp. 269-293. Oxford University Press, New York.

Furtado, E. P. H. and V. Karan (1990). 'Causes, Consequences, and Shareholder Wealth Effects of Management Turnover: a Review of the Empirical Evidence', Financial Management, 19(2), pp. 60-75.

Gamson, W. and N. Scotch (1964). 'Scapegoating in Baseball', American Journal of Sociology, 70, pp. 69-70.

Goodstein, J. and W. Boeker (1991). 'Turbulence at the Top: a New Perspective on Governance Structure Changes and Strategic Change', Academy of Management Journal, 34, pp. 306-330.

Greiner, L. and A. Bhambri (1989). 'New CEO Intervention and Dynamics of Deliberate Strategic Change', Strategic Management Journal, 10, pp. 67-86.

Griffith, J. R. (1987). The Well-managed Community Hospital. Health Administration Press, Ann Arbor, MI.

Hambrick, D. C. and A. A. Cannella (1993). 'Relative Standing: a Framework for Understanding Departures of Acquired Executives', Academy of Management Journal, 36, pp. 733-762.

Hambrick, D. C. and G. Fukutomi (1991). 'The Seasons of a CEO's Tenure', Academy of Management Review, 16, pp. 719-742.

Hannan, M. T. and A. A. Young (1977). 'Estimation in Panel Models: Results on Pooling Cross-sections and Time Series'. In: D. R. Heise (ed.), Sociological Methodology 1977, pp. 52-83. Jossey-Bass, San Francisco.

Harrison, J. S., M. A. Hitt, R. E. Hoskisson and R. D. Ireland (1991). 'Synergies and Post-acquisition Performance: Differences versus Similarities in Resource Allocations', Journal of Management, 17, pp. 173-190. 
Haspeslagh, P. C. and D. B. Jemison (1991). Managing Acquisitions: Creating Value Through Corporate Renewal. Free Press, New York.

Hedberg, B. (1981). 'How Organizations Learn and Unlearn'. In: P. C. Nystrum and W. H. Starbuck (eds), Handbook of Organizational Design, Vol. 1: Adapting Organizations to their Environments, pp. 3-27. Oxford University Press, New York.

Hill, C. and P. Phan (1991). 'CEO Tenure as a Determinant of CEO Pay', Academy of Management Journal, 34, pp. 707-717.

Hill C. W. L. and R. E. Hoskisson (1987). 'Strategy and Structure in the Multiproduct Firm', Academy of Management Review, 12, pp. 331-341.

Hollingsworth, J. R. and E. J. Hollingsworth (1987). Controversy about American Hospitals: Funding, Ownership, and Performance. American Enterprise Institute for Public Policy Study, Washington DC.

James, D. R. and M. Soref (1981). 'Profit Constraints on Managerial Autonomy: Managerial Theory and the Unmaking of the Corporate President', American Sociological Review, 46, pp. 1-18.

Jemison, D. B. and S. B. Sitkin (1986). 'Corporate Acquisitions: a Process Perspective', Academy of Management Review, 11, pp. 145-163.

Jensen, M. C. (1986). 'Agency Costs of Free Cash Flow, Corporate Finance and Takeovers', American Economic Review, 76, pp. 323-329.

King, G., R. O. Keohane and S. Verba (1994). Designing Social Inquiry: Scientific Inference in Qualitative Research. Princeton University Press, Princeton, NJ.

Kitching, J. (1967). 'Why do Mergers Miscarry?', Harvard Business Review, 45(6), pp. 84-101.

Kleinbaum, D. G., L. L. Kupper and K. E. Muller (1988). Applied Regression Analysis and other Multivariable Methods. PWS-Kent Publishing Company, Boston.

Levinthal, D. (1994). 'Surviving Schumpeterian Environments: an Evolutionary Perspective'. In: J. A. C. Baum and J. V. Singh (eds), Evolutionary Dynamics of Organizations, pp. 167-178. Oxford University Press, New York.

McEachern, W. A. (1975). Managerial Control and Performance. Heath, Lexington, MA.

March, J. G. and H. A. Simon (1993). 'Organizations Revisited', Industrial and Corporate Change, $\mathbf{2}$, pp. 299-316.

Martin, K. J. and J. J. McConnell (1991). 'Corporate Performance, Corporate Takeovers, and Management Turnover', Journal of Finance, 46, pp. 671-687.

Meyer, M. W. (1978). 'Leadership and Organizational Structure'. In: M. W. Meyer and Associates, Environments and Organizations, pp. 200-232. Jossey-Bass, San Francisco.

Miller, D. (1991). 'Stale in the Saddle: CEO Tenure and the Match between Organization and Environment', Management Science, 37, pp. 3-52.

Miller, D. (1993). 'Some Organizational Consequences of CEO Succession', Academy of Management Journal, 36, pp. 644-659.

Mintzberg, H. (1983). Power In and Around Organizations. Prentice-Hall, Englewood Cliffs, NJ.

Morrisey, M. A. and J. A. Alexander (1987). 'Hospital Participation in Multihospital Systems', Advances in Health Economics and Health Services Research, 7, pp. 59-81.
Office of Technology Assessment (1985). Medicare's Prospective Payment System. US Government Printing Office, Washington DC.

Pablo, A. L. (1994). 'Determinants of Acquisition Integration Level: a Decision-making Perspective', Academy of Management Journal, 37, pp. 803-836.

Pfeffer, J. (1981). 'Management as Symbolic Action: the Creation and Maintenance of Organizational Paradigms'. In: B. M. Staw and L. L. Cummings (eds), Research in Organizational Behavior, Vol. 3, pp. 1-52. JAI Press, Greenwich, Conn.

Pfeffer, J. (1982). Organizations and Organization Theory. Pitman, Boston.

Pfeffer, J. and G. R. Salancik (1977). 'Organizational Context and the Characteristics and Tenure of Hospital Administrators', Academy of Management Journal, 20, pp. 74-88.

Pfeffer, J. and G. R. Salancik (1978). The External Control of Organizations: a Resource Dependence Perspective. Harper and Row, New York.

Salancik, G. R. and J. Pfeffer (1980). 'Effects of Ownership and Performance on Executive Tenure in U.S. Corporations', Academy of Management Journal, 23, pp. 653-664.

Scott, W. R. (1992). Organizations: Rational, Natural, and Open Systems. Prentice-Hall, Englewood Cliffs, NJ.

Sherman, H. D. (1984). 'Hospital Efficiency Measurement and Evaluation: Empirical Test of a New Technique', Medicare Care, 22, pp. 922-935.

Shortell, S. M. (1988). 'The Evolution of Hospital Systems: Unfulfilled Promises and Self-fulfilling Prophesies', Medical Care Review, 45, pp. 177-214.

Singh, H. and C. Montgomery (1987). 'Corporate Acquisition Strategies and Economic Performance', Strategic Management Journal, 8, pp. 377-386.

Sofaer, S. and R. C. Myrtle (1991). 'Interorganizational Theory and Research: Implications for Health Care Management, Policy, and Research', Medical Care Review, 48, pp. 371-409.

Starkweather, D. B. (1981). Hospital Mergers in the Making. Health Administrative Press, Ann Arbor, MI.

Tushman, M. L. and E. Romanelli (1985). 'Organizational Evolution: a Metamorphosis Model of Convergence and Reorientation'. In: L. L. Cummings and B. M. Staw (eds), Research in Organizational Behavior, Vol 7, pp. 171-222. JAI Press, Greenwich, CT.

Varian, H. R. (1988). 'Symposium on Takeovers', Journal of Economic Perspectives, 2(1), pp. 3-5.

Virany, B., M. L. Tushman and E. Romanelli (1992). 'Executive Succession and Organization Outcomes in Turbulent Environments: an Organization Learning Approach', Organization Science, 3, pp. 72-91.

Walsh, J. P. (1988). 'Top Management Turnover Following Mergers and Acquisitions', Strategic Management Journal, 9, pp. 173-183.

Walsh, J. P. (1989). 'Doing a Deal: Merger and Acquisition Negotiations and their Impact upon Target Company Top Management Turnover', Strategic Management Journal, 10, pp. 307-322.

Walsh, J. P. and J. W. Ellwood (1991). 'Mergers, Acquisitions, and the Pruning of Management Deadwood', Strategic Management Journal, 12, pp. 201-217.

Walsh, J. P. and R. D. Kosnik (1993). 'Corporate Raiders and their Disciplinary Role in the Market for Corporate Control', Academy of Management Journal, 36, pp. 671-700. 
Walsh, J. P. and J. K. Seward (1990). 'On the Efficiency of Internal and External Corporate Control Mechanisms', Academy of Management Review, 15, pp. 421-458.

Wegmiller, D. C. (1985). 'Management Issues in the Development and Maturation of Multihospital Systems', Health Care Management Review, 10, pp. 9-17.

Weil, P. A. (1990). 'Job Turnover of CEOs in Teaching and Nonteaching Hospitals', Academic Medicine, 65(1), pp. 1-7.

Weil, P. A. and J. Timmerberg (1990). 'Hospital CEO Turnover: Modeling More or Less Desirable Places to Work', Health Services Management Research, 3, pp. 208-217.
Wiersema, M. F. and K. A. Bantel (1993). 'Top Management Team Turnover as an Adaptation Mechanism: the Role of the Environment', Strategic Management Journal, 14, pp. $485-504$.

Yamaguchi, K. (1991). Event History Analysis. Sage, Newbury Park, CA.

Zeger, S. L. and K-Y. Liang (1992). 'An Overview of Methods for the Analysis of Longitudinal Data', Statistics in Medicine, 11, pp. 1825-1839. 